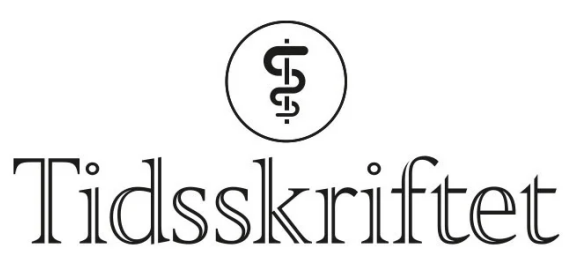

DEN NORSKE LEGEFORENING

\title{
Behov for bedre kunnskap og praksis
}

\author{
ANMELDELSER
}

INGER HELENE VANDVIK

Slependen

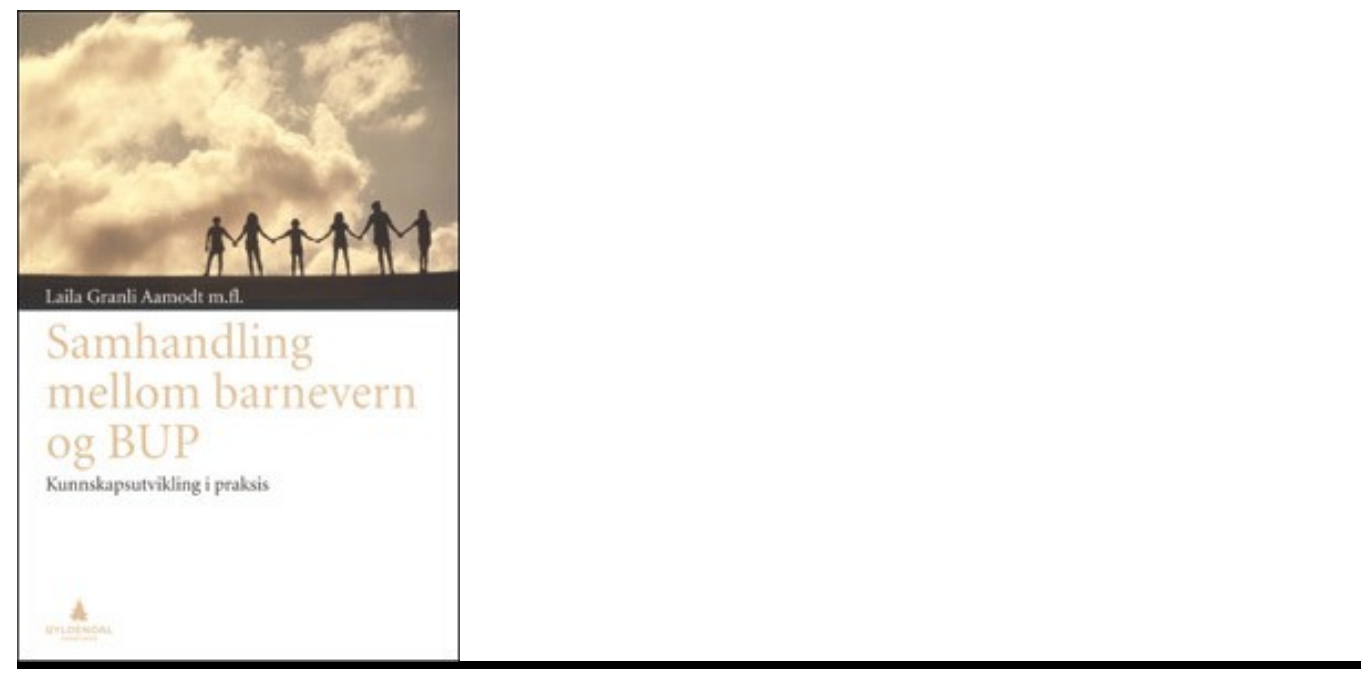

Aamodt, Laila Granli

Samhandling mellom barnevern og BUP

Kunnskapsutvikling i praksis. 333 s, ill. Oslo: Gyldendal Akademisk, 2011. Pris NOK 425

ISBN 978-82-05-41212-5

Hovedforfatter er klinisk sosionom med bred erfaring fra arbeid med barn og unge i familier med alvorlige og sammensatte problemer. De tre medforfatterne er barnevernspedagoger. Målgruppen er studenter i helse- og sosialutdanningene på høyskoler og universiteter, men de ønsker også å nå de som arbeider innen videre- og etterutdanning i barneverntjenesten og psykisk helsevern - og ikke minst politikerne som legger premissene for de strukturelle rammene for tjenestene.

Fremstillingen bygger på praktisk erfaring og tar utgangspunkt i Familien $i$ sentrum, et samarbeidsprosjekt som ble gjennomført i Bærum kommune i årene 2006-08. Boken er delt i tre deler. Den første delen handler om erfaringer og studier som dokumenterer behov 
for ny praksis i etablerte tjenester. Den andre delen omhandler teori og kunnskap i praksis - for praksis, og siste del dreier seg om endringer for praksis - i praksis. Litteraturlisten og stikkordregisteret dekker de temaene som belyses.

Til sammen er det 23 kapitler, inklusive ettertanker etter hvert kapittel. Forfatterne beskriver ulike arbeidsmåter (dialogmøter, nettverks- og oppstartsmøter) som kan bidra til bedring av samhandlingen mellom familien, familiens nettverk og tjenestene de har kontakt med. De utfordringene og misoppfatningene som instansene, og spesielt barnevernet og barne- og ungdomspsykiatrisk poliklinikker (BUP), står overfor, belyses bl.a. ved tallrike sitater fra brukere og ansatte. Arbeid for å sikre at hjelpere bidrar til at familier som trenger bistand, får en hjelp de selv finner viktig, vektlegges. Videre legger forfatterne vekt på at barn og unge med alvorlig psykososial problematikk må sikres psykisk helsehjelp og prioriteres i BUP i større grad enn i dag.

Modeller for samarbeid og samhandling mellom instanser og dialog med pasient/bruker og familie er selvsagt både viktig og relevant. Dette er hovedbudskapet, men det blir for mange gjentakelser, mens eksisterende kunnskap og behov for utvikling av klinisk kompetanse om de komplekse biopsykososiale forholdene som kan danne grunnlag for hjelpebehov fra barnevern og BUP, knapt er nevnt. Sitater fra ansatte og fokusgrupper kan avspeile skepsis og til dels negative oppfatninger av hva en diagnose eller diagnostisk kartlegging kan innebære. Det er mange eksempler på svikt i kommunikasjonen mellom instansene og med pasient/bruker og pårørende.

Forfatterne dokumenterer mange viktige og relevante utfordringer for å bedre samhandling mellom barnevern og psykisk helsetjeneste. Men boken er mindre egnet til å gi et bedre kunnskapsgrunnlag for god klinisk praksis innen BUP eller barnevern.

Publisert: 29. november 2011. Tidsskr Nor Legeforen. DOI: 10.4045/tidsskr.11.1097

(C) Tidsskrift for Den norske legeforening 2023. Lastet ned fra tidsskriftet.no 26. april 2023. 